\title{
Spatial heterogeneity of bacterial communities in the mucus of Montastraea annularis
}

\author{
Camille A. Daniels ${ }^{1}$, Amy Zeifman ${ }^{1}$, Kathy Heym ${ }^{2,}{ }^{5}$, Kim B. Ritchie ${ }^{3}$, \\ Craig A. Watson ${ }^{2}$, Ilze Berzins ${ }^{4,6}$, Mya Breitbart ${ }^{1, *}$ \\ ${ }^{1}$ University of South Florida, College of Marine Science, 140 7th Avenue South, St. Petersburg, Florida 33701, USA \\ ${ }^{2}$ University of Florida/IFAS Tropical Aquaculture Laboratory, 1408 24th Street SE, Ruskin, Florida 33570, USA \\ ${ }^{3}$ Mote Marine Laboratory, 1600 Ken Thompson Parkway, Sarasota , Florida 34236, USA \\ ${ }^{4}$ The Florida Aquarium, 701 Channelside Drive, Tampa, Florida 33602, USA \\ ${ }^{5}$ Present address: Sea World Orlando, 7007 Sea World Drive, Orlando, Florida 32821, USA \\ ${ }^{6}$ Present address: John G. Shedd Aquarium, 1200 South Lake Shore Drive, Chicago, Illinois 60605, USA
}

\begin{abstract}
Corals are known to contain a diverse microbiota; however, few studies have explicitly addressed the spatial variability of bacterial communities across individual, healthy coral colonies. This study applied culture-based and culture-independent methods to examine the spatial heterogeneity in bacterial communities in the mucus of 3 healthy Montastraea annularis colonies from Looe Key Reef, Florida Keys. Automated ribosomal intergenic spacer analysis (ARISA) results showed significant variability (up to $61 \%$ dissimilarity) in the composition of the total bacterial community at different locations only centimeters apart on individual coral colonies. Abundances of culturable Vibrio spp. determined by TCBS plating were highly variable across individual coral colonies, differing by up to 100-fold between different locations on the same colony. ARISA profiles indicated that intracolony variation rivaled intercolony differences in the composition of the culturable Vibrio community (i.e. types of culturable Vibrio spp. and their relative abundances). The high degree of spatial heterogeneity in coral-associated bacteria observed across individual colonies has implications for coral microbiology studies and coral restoration projects.
\end{abstract}

KEY WORDS: Community profiling $\cdot$ ARISA $\cdot$ Bacteria $\cdot$ Coral $\cdot$ Spatial heterogeneity $\cdot$ Vibrio Resale or republication not permitted without written consent of the publisher

\section{INTRODUCTION}

Corals harbor abundant and diverse microbial communities, with approximately 100 million bacteria $\mathrm{cm}^{-2}$ of coral surface (Ritchie et al. 1994, Ritchie \& Smith 1997, 2004, Rohwer et al. 2001, 2002, Wegley et al. 2004, 2007, Bourne \& Munn 2005, Koren \& Rosenberg 2006, Ritchie 2006). Bacterial concentrations in coral mucus are 100- to 1000-fold greater than those in ambient seawater (Ducklow \& Mitchell 1979a, Wild et al. 2004), and the coral bacterial communities are often species-specific associations that are maintained over time and space (Ritchie \& Smith 1997, Rohwer et al. 2002). Bacteria play a myriad of critical roles for coral ecology, including nutrient acquisition (Shashar et al.
1994, Lesser et al. 2004, Beman et al. 2007, Wegley et al. 2007) and antibiotic production (Ritchie 2006, Nissimov et al. 2009, Shnit-Orland \& Kushmaro 2009). In addition, it has also been suggested that changes in the microbial community can allow corals to rapidly adapt to changing environmental conditions (Brown \& Bythell 2005, Reshef et al. 2006, Kooperman et al. 2007, Rosenberg et al. 2007). Recent studies indicate that corals may regulate the activity of their associated bacterial communities (Breitbart et al. 2005, Kline et al. 2006, Rohwer et al. 2010). Certain factors, most notably the addition of dissolved organic carbon to concentrations above field-observed averages, cause this regulation of coral-related bacteria to break down, leading to coral decline (Kline et al. 2006, Smith et al. 2006). Shifts 
in bacterial community composition have been observed in bleached and diseased corals, with opportunists and pathogens present in these health-compromised states (Ritchie \& Smith 1995, Kushmaro et al. 1997, Frias-Lopez et al. 2002, Pantos et al. 2003, Pantos \& Bythell 2006, Ritchie 2006, Bourne et al. 2008).

The coral surface layers are extremely complex and dynamic (Ainsworth et al. 2006, Johnston \& Rohwer 2007); however, few studies have examined spatial heterogeneity in coral-microbe associations across individual coral colonies. In diseased coral colonies, significant differences have been observed between the bacteria found in the healthy versus diseased portions of the colony (Frias-Lopez et al. 2002, Pantos et al. 2003, Breitbart et al. 2005, Gil-Agudelo et al. 2006, 2007, Pantos \& Bythell 2006, Sekar et al. 2006). A limited number of studies have also demonstrated spatial variation in the bacterial community associated with healthy branching corals. Rohwer et al. (2002) demonstrated that bacterial communities were spatially structured on the branching coral Porites furcata, with specific bacterial taxa only found at the branch tips. In addition, bacterial community analysis in 6 replicate tissue samples from healthy Pocillopora damicornis colonies revealed spatial heterogeneity across some coral colonies (Bourne \& Munn 2005), although some bacteria were uniformly found throughout an individual coral colony. Hansson et al. (2009) also demonstrated that the cold water coral Madrepora oculata exhibited spatial variation of bacterial communities within and among colonies, yet a Spongiobacter sp. was consistently found in all healthy samples.

The degree of spatial complexity in coral-associated bacteria has implications for our understanding of the health and ecology of the coral holobiont. The present study utilized both culture-based and culture-independent methods to determine the extent of spatial heterogeneity of the bacterial community in mucus sampled from various locations across the surface of individual Montastraea annularis colonies from the Florida Keys. In addition to the total bacterial community, the abundance and diversity of cultured Vibrio spp. was addressed, since this bacterial group has been extensively examined in coral microbiology research. The results showed a significant amount of spatial heterogeneity across individual colonies, although some members of the microbial community were present at all locations sampled on a colony. Abundances of culturable Vibrio spp. were highly variable across individual coral colonies, suggesting that this parameter should not be used to indicate coral health. The observed spatial heterogeneity of bacteria in mucus from individual coral colonies has important implications for coral microbiology studies and coral restoration projects.

\section{MATERIALS AND METHODS}

Sample collection. The surface mucus layers of 3 apparently healthy Montastraea annularis colonies (MA1, MA2, MA3) were sampled in situ at Looe Key Reef, in the lower Florida Keys $\left(24^{\circ} 32.75^{\prime} \mathrm{N}\right.$, $81^{\circ} 24.35^{\prime} \mathrm{W}$ ) in July 2009. Several random locations (approx. $12 \mathrm{~cm}^{2}$ each, constrained through the use of $4 \mathrm{~cm}$ diameter PVC pipe) were sampled from the sunfacing tops of each coral colony (Fig. 1). Using sterile blunt-end syringes, the surface of the coral was briefly disturbed and $12 \mathrm{ml}$ mucus samples were aspirated, with efforts to minimize the amount of surrounding
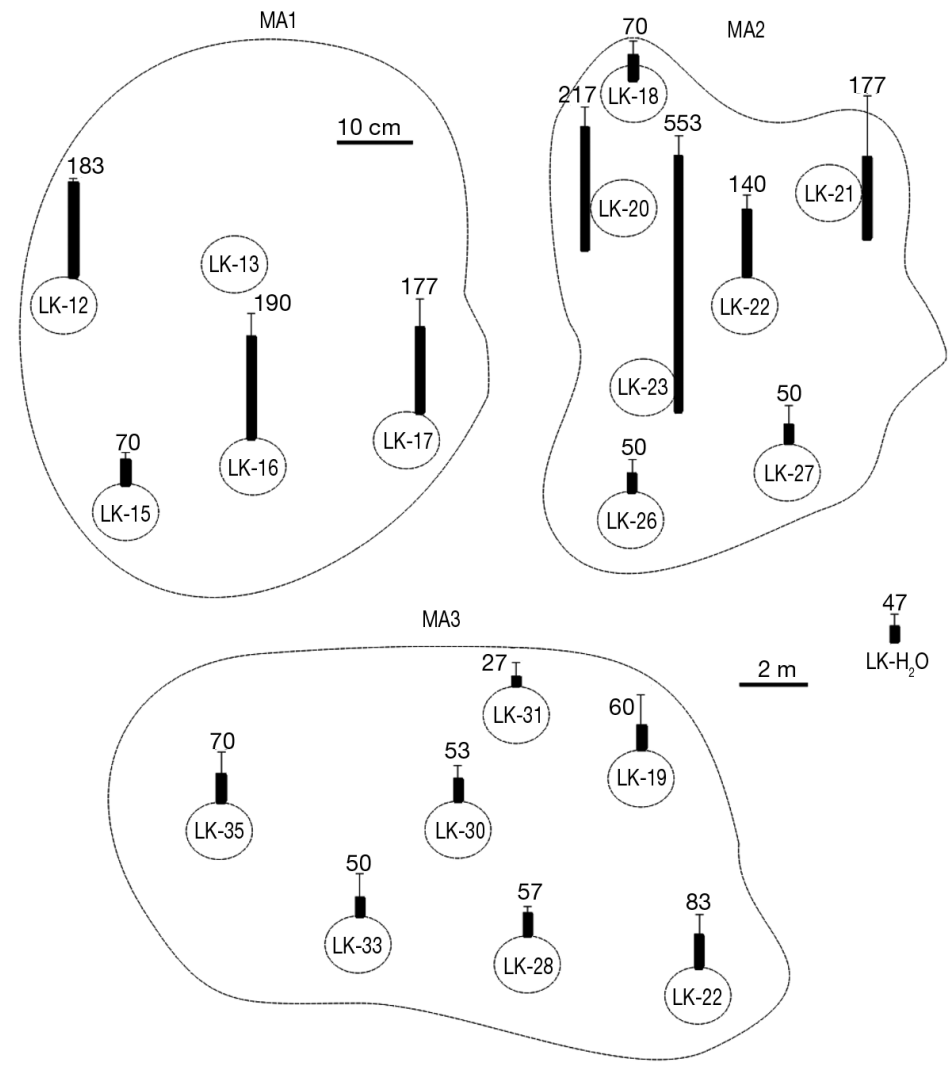

Fig. 1. Top-down view demonstrating approximate locations of each sample on individual Montastraea annularis colonies (MA1, MA2, MA3) as well as the spatial arrangement of the colonies at the Looe Key (LK) reef site. Distances between spots within a colony are measured at the $10 \mathrm{~cm}$ scale and distances between colonies are measured at the $2 \mathrm{~m}$ scale. Sample number is designated by LK-no. The bar size and number above the bar represent culturable Vibrio spp. abundance for each sample (colony forming units [CFU] $\mathrm{ml}^{-1}$ ) 
seawater collected. MA1 and MA2 were located approximately $2 \mathrm{~m}$ apart, while MA3 was $5 \mathrm{~m}$ away; all colonies were at a depth of $5.5 \mathrm{~m}$. An ambient water sample (1 l) was also collected approximately $1 \mathrm{~m}$ above the reef. Mucus and water samples were stored on ice until return to the laboratory (within $2 \mathrm{~h}$ ), where they were processed immediately for culturebased analyses. The remaining fractions of all coral mucus samples were frozen at $-80^{\circ} \mathrm{C}$, and the water sample was filtered onto a $0.2 \mu \mathrm{m}$ Sterivex filter (Millipore, Billerica) and then stored at $-80^{\circ} \mathrm{C}$.

Molecular profiling of total bacterial community by ARISA. Bacteria were concentrated from $10 \mathrm{ml}$ of the coral mucus samples through centrifugation at $15000 \times g$ for $15 \mathrm{~min}$. Mucus pellets from individual locations across Montastraea annularis colonies and the Sterviex filter from the Looe Key seawater sample were extracted with a PowerSoil DNA Kit (MO-BIO) according to the manufacturer's instructions, with an extended (30 min) bead beating step and elution of DNA into sterile water instead of kit buffer. DNA was stored at $-20^{\circ} \mathrm{C}$.

Automated ribosomal intergenic spacer analysis (ARISA) (Borneman \& Triplett 1997, Fisher \& Triplett 1999), which relies on the variable length of the intergenic spacer (ITS) region between the $16 \mathrm{~S}$ and $23 \mathrm{~S}$ ribosomal RNA, was used to profile the total bacterial community. ARISA profiling was chosen based on its low cost, fast sample processing, high level of reproducibility, and ability to detect differences in bacterial community composition (Hewson \& Fuhrman 2004, Danovaro et al. 2006). Following a modified protocol of Danovaro et al. (2006), $50 \mu$ l ARISA-PCR mixtures contained $10 \mu \mathrm{M}$ universal bacterial primers 16S1392F (5'-GYA CAC ACC GCC CGT-3') and fluorescently labelled 23S-125R-HEX (5'-HEX-GGG TTB CCC CAT TCR G-3'), 0.2 mM dNTPs, $100 \mu \mathrm{g} \mathrm{m}^{-1}$ BSA, $1 \times$ Red Taq buffer (10 mM Tris- $\mathrm{HCl}, \mathrm{pH} 8.3,50 \mathrm{mM}$ $\mathrm{KCl}, 1.1 \mathrm{mM} \mathrm{MgCl}$ ), $1 \mathrm{U}$ RedTaq DNA Polymerase (Sigma-Aldrich), and $5 \mu \mathrm{l}$ of DNA template. Thermocycling conditions consisted of a $3 \mathrm{~min}$ initial denaturation at $94^{\circ} \mathrm{C}$, followed by 30 cycles of $94^{\circ} \mathrm{C}$ for $1 \mathrm{~min}$, $55^{\circ} \mathrm{C}$ for $1 \mathrm{~min}$, and $72^{\circ} \mathrm{C}$ for $2 \mathrm{~min}$, and a final extension of $10 \mathrm{~min}$ at $72^{\circ} \mathrm{C}$. Triplicate PCR products were purified with a DNA Clean \& Concentrator Kit (Zymo Research) and quantified using a Quant-IT ${ }^{\mathrm{TM}}$ Pico Green Assay Kit (Invitrogen).

Purified PCR products were normalized by diluting to $5 \mathrm{ng} \mathrm{ul}^{-1}$ for each sample and sent to the University of Illinois Urbana-Champaign for capillary electrophoresis runs. ARISA profiles were generated by combining $1 \mu$ l of cleaned ARISA-PCR product with ROX 1000 (Applied Biosystems) internal size standard, and deionized formamide. This mixture was denatured at $95^{\circ} \mathrm{C}$ for $2 \mathrm{~min}$, and placed on ice. Each mixture was loaded into a separate capillary on an ABI Prism 3730xl Genetic Analyzer (Applied BioSystems), which separates DNA fragments by size (where each peak represents an operational taxonomic unit [OTU]), and detects fluorescence produced by those fragments (relative abundance). Control bacterial communities, ranging from a single bacterial isolate to a complex seawater sample, were run in triplicate to determine the accuracy of the ABI 3730xl ( $\pm 1 \mathrm{bp}$, data not shown). Replicates performed on these controls demonstrated that this method is robust and reproducible.

ARISA profile analysis. Fragments were sized from the raw electropherograms using the Local Southern calling method in Peak Scanner v.1.0 software (Applied Biosystems). Since accurate sizing of peaks is typically limited to $\leq 1 \mathrm{~kb}$ and small fragments are typically considered artifacts (Fisher \& Triplett 1999), only profile peaks between 300 to $1000 \mathrm{bp}$ were retained for analysis. Raw profiles were further filtered using the following standardization criteria: (1) exclusion of peaks less than 5 times the baseline signal, (2) removal of shoulder peaks (Fisher \& Triplett 1999, Danovaro et al. 2006, Luna et al. 2006), and (3) exclusion of peaks not present in 2 of 3 triplicate profiles (Hewson \& Fuhrman 2004). Binning of ARISA data has been shown to correct for methodological variation that would otherwise be misconstrued as ecological variability (Hewson \& Fuhrman 2006). The interactive binner developed by Ramette (2009) was used to apply a $2 \mathrm{bp}$ bin across ARISA profiles to account for detector error and technical variation inherent to peak sizing. All profiles were subsequently examined visually to ensure proper binning of peaks. Binned peak data (OTUs contributing $\geq 0.09 \%$ of total fluorescence) was imported into Excel (Microsoft), where the average area under each peak was calculated between triplicates to produce a single composite profile for each sample, and peak areas were normalized to reflect the percent contribution of each peak to the total profile fluorescence (Hewson \& Fuhrman 2004).

Statistical analyses were run in the PRIMER software package (Clarke 1993) and MATLAB v.7.8 (MathWorks) to determine the extent of similarity between bacterial community profiles from distinct locations across each coral colony. Square-root transformed ARISA fluorescence data was used to calculate BrayCurtis distances (Bray \& Curtis 1957), which represent similarity based on OTU composition and abundance. Resemblance matrices were generated from pairwise comparisons of these values and hierarchical cluster diagrams were produced to display dissimilarities between ARISA profiles. Bray-Curtis values from sample comparisons within the same colony were averaged to calculate the mean intracolony dissimilarity. The intercolony values were also calculated using 
these same resemblance matrices. Analysis of similarity (ANOSIM), which compares ranks of distances, was performed to determine whether intercolony profiles were significantly different from intracolony profiles. An approach less inclined to produce Type I errors, but analogous to ANOSIM, is permutational multivariate analysis of variance (PERMANOVA) (Anderson 2001). This test compares the means of distances among versus within groups to produce an F-statistic, and a p-value is generated through random permutation. Because PERMANOVA assumes equal variances for intracolony samples, nonparametric dispersion analysis (NP-DISP), which calculates distances to a colony centroid from each sample profile within each colony, was used to confirm that the ARISA data did not violate the assumption of homogenous dispersion (Anderson 2006). Five thousand permutations were conducted for all tests and a p-value $\leq 0.01$ was considered significant. Similarity percentage (SIMPER) analyses were also conducted to determine which OTUs contributed to dissimilarity among samples.

Identification of ARISA OTUs. Taxonomic characterization of ARISA OTUs was performed using an identical PCR to that described above for ARISA, except the reverse primer did not contain the HEX fluorophore. Total community PCR products from samples LK-17, 21, and 33 (one from each coral colony) were cloned into a pCR4-TOPO vector, which were transformed into chemically competent $E$. coli cells following the TOPO TA kit protocol (Invitrogen). Clones were screened to identify insert sizes consistent with the OTUs of interest identified from the ARISA profiles using the Agilent Bioanalyzer DNA7500 assay, as per manufacturer's instructions. Multiple OTUs of identical sizes across different samples were also sequenced to validate that these peaks were produced by the same bacterial taxa. Cloned ARISA PCR products were sequenced bi-directionally with $1392 \mathrm{~F}$ and $125 \mathrm{R}$ primers, and sequence data was trimmed for vector removal and quality in Sequencher (Genecodes). The complete sequence (accession numbers: HM209393-HM209399) from each clone was compared using BLASTN (www.ncbi.nlm.nih.gov/blast) against the National Center for Biotechnology Information (NCBI)'s GenBank non-redundant database to assess the degree of nucleotide identity to known sequences (Altschul et al. 1990). BLAST assignments of ARISA clones were further confirmed by the Ribosomal Database Project CLASSIFIER, a highly curated and annotated database that applies a Bayesian algorithm to classify $16 \mathrm{~S}$ sequence data into taxonomic categories (Wang et al. 2007).

Abundance and diversity of culturable Vibrio spp. Vibrio is a genus of marine bacteria found in the mucus and tissues of healthy corals (Koren \& Rosen- berg 2006), where their presence and abundance varies seasonally (Ritchie 2006, Bourne et al. 2008). In addition, some members of this group are pathogens associated with a number of coral diseases (Kushmaro et al. 2001, Ben-Haim et al. 2003a, Cervino et al. 2008, Sussman et al. 2008). Kline et al. (2006) demonstrated that Vibrio spp. from healthy corals induced mortality when re-introduced at higher concentrations, suggesting that the concentration of Vibrios has important implications for coral health. The abundance and diversity of culturable Vibrio spp. at distinct locations across the coral colonies was examined by culturing mucus samples on thiosulfate citrate bile salts (TCBS, Neogen) agar, a growth media formulated to select for Vibrio spp. (Lotz et al. 1983). Immediately upon return to the laboratory, samples were vortexed and $100 \mu \mathrm{l}$ of mucus from each sample was plated onto TCBS agar in triplicate. The number of colonies was determined after $48 \mathrm{~h}$ of incubation at room temperature. All colonies from 2 replicate plates for each sample were scraped into a single microcentrifuge tube with sterile toothpicks to create a culturable Vibrio community fraction for comparison to total bacteria ARISA profiles, and stored at $-80^{\circ} \mathrm{C}$. Ten colonies from the remaining replicate plate were also archived as individual isolates at $-80^{\circ} \mathrm{C}$. DNA was extracted from the culturable Vibrio community fraction using the DNeasy Tissue Kit (Qiagen) according to manufacturer's instructions, with final DNA eluted into sterile water instead of kit buffer. ARISA profiling was performed on the Vibrio community fraction and isolates as described above.

\section{RESULTS}

\section{Total community profiles}

To examine inter- and intra-colony heterogeneity in coral-associated bacterial communities, ARISA profiles were generated from mucus samples collected at multiple distinct locations on 3 different Montastraea annularis colonies (MA1, MA2, MA3) from Looe Key Reef in the Florida Keys. On average, 47 OTUs (size range 301-968 bp) were detected in the coral mucus samples, while the overlying water sample contained 70 OTUs (size range 301-962 bp) (Fig. 2). Some overlap in OTUs was observed between the ARISA profiles from the water column versus the coral mucus samples; however, Bray-Curtis dissimilarity values demonstrate that the coral mucus bacterial profiles were distinct from the bacterial community found in the overlying water column (Figs. 2 \& 3). The 2 most abundant OTUs in the water sample (P491 and P595), which together accounted for $22 \%$ of total profile fluores- 


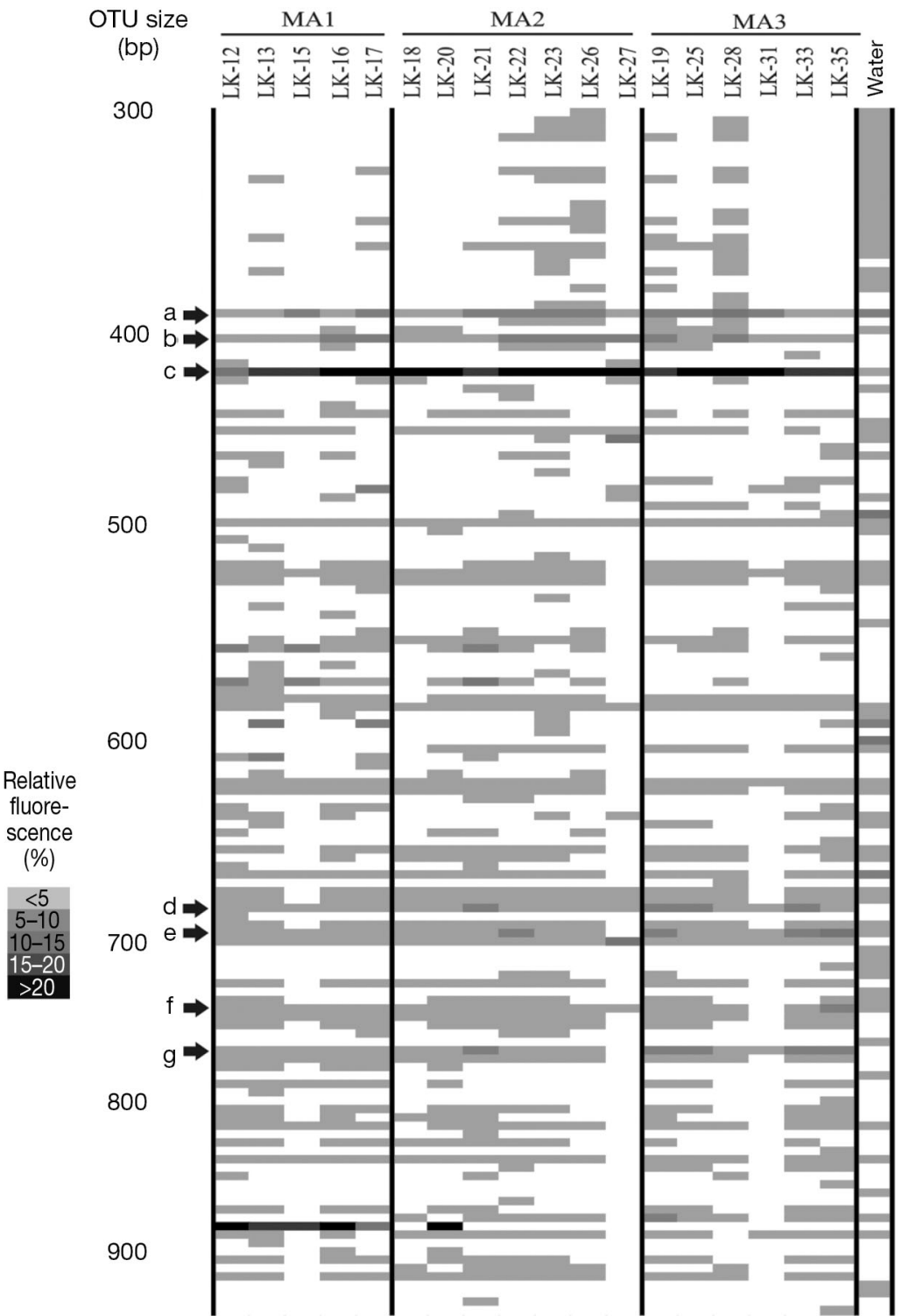

Fig. 2. Total bacterial community operational taxonomic units (OTUs) from ARISA profiles of individual samples across 3 Montastraea annularis colonies. The letter designations represent the ARISA OTUs selected for cloning and sequencing and correspond to letter designations in Table 1. Relative fluorescence values are displayed as percentage contributions of individual OTUs to total profile fluorescence

cence, were not detected in the majority of the coral mucus samples (Fig. 2).

Average total community profiles from the 3 Montastraea annularis colonies at Looe Key Reef were significantly different from each other (1-way ANOSIM, R = $0.41, \mathrm{p}<0.001$ and PERMANOVA, $F=2.94, \mathrm{p}<0.001)$. A low $\mathrm{R}$ value demonstrated overlap in total bacterial community composition, but an average dissimilarity of $31 \%$ was observed between the 3 colonies (Fig. 3). Pairwise comparisons of colonies demonstrated that MA1 was significantly different from MA2 (1-way
ANOSIM, $\mathrm{R}=0.36, \mathrm{p}<0.001$ and PERMANOVA, $F=1.64, \mathrm{p}=0.01$ ) and MA3 (1-way ANOSIM, $\mathrm{R}=0.51, \mathrm{p}<0.001$ and PERMANOVA, $F=1.90, \mathrm{p}<0.01)$.

Overall, ARISA profiles from individual locations within a colony were more likely to be grouped together than ARISA profiles chosen at random from the 3 different colonies; however, there were several exceptions to this pattern (e.g. LK-27 and LK-31; Fig. 3). A focus on the intracolony profiles revealed a high level of variability (9 to $61 \%$ dissimilarity) for samples taken only $10 \mathrm{~s}$ of $\mathrm{cm}$ apart. For example, the total bacterial community profile from LK-31 is $50 \%$ dissimilar to most other samples from MA3 (Fig. 3). Several individual samples (i.e. LK-16, LK-20, and LK-28) were more similar to samples taken from different colonies than to other samples from their original colony (Fig. 3).

Although the ARISA profiles from each of the coral mucus samples shared many OTUs, 8 OTUs were consistently detected in every coral mucus sample (Fig. 2). SIMPER analysis indicated that differences in the abundance of 3 of these 8 OTUs (P393, P403, and P419) contributed 20 to $25 \%$ of the variation of samples within a colony. Sequencing of P393 revealed that this OTU was $92 \%$ identical to an uncultured marine bacterial clone from the San Pedro Ocean Time Series (SPOTS) (Brown et al. 2005), and comparison to the Ribosomal Database Project (RDP) further resolved P393 as a gammaproteobacterium (Table 1). P419 was abundant in all the Montastraea annularis mucus samples (10.8 to $69.8 \%$ of total fluorescence in individual profiles), but was also found in the water sample at lower abundance (4.2\% of total fluorescence). P419 was 99\% identical to an uncultured marine bacterial clone from SPOTS (Brown et al. 2005), and further resolved as an actinobacterium based on comparison to the RDP (Table 1). Many OTUs (e.g. P533, P577, P617, P693, P697, P740, P742, P766, P770, and P841) were found in the vast majority of the coral mucus samples across all colonies, but absent in one or more of the individual coral samples (Fig. 2). Several of these OTUs were sequenced and found to have $<94 \%$ identity to previously sequenced bacteria (Table 1). P892 was predominantly found on only one coral colony and SIMPER analysis showed this OTU was responsible for $10 \%$ of the observed variation, demonstrating intercolony variability in bacterial community composition. Other OTUs were only detected sporadically amongst the coral samples. 


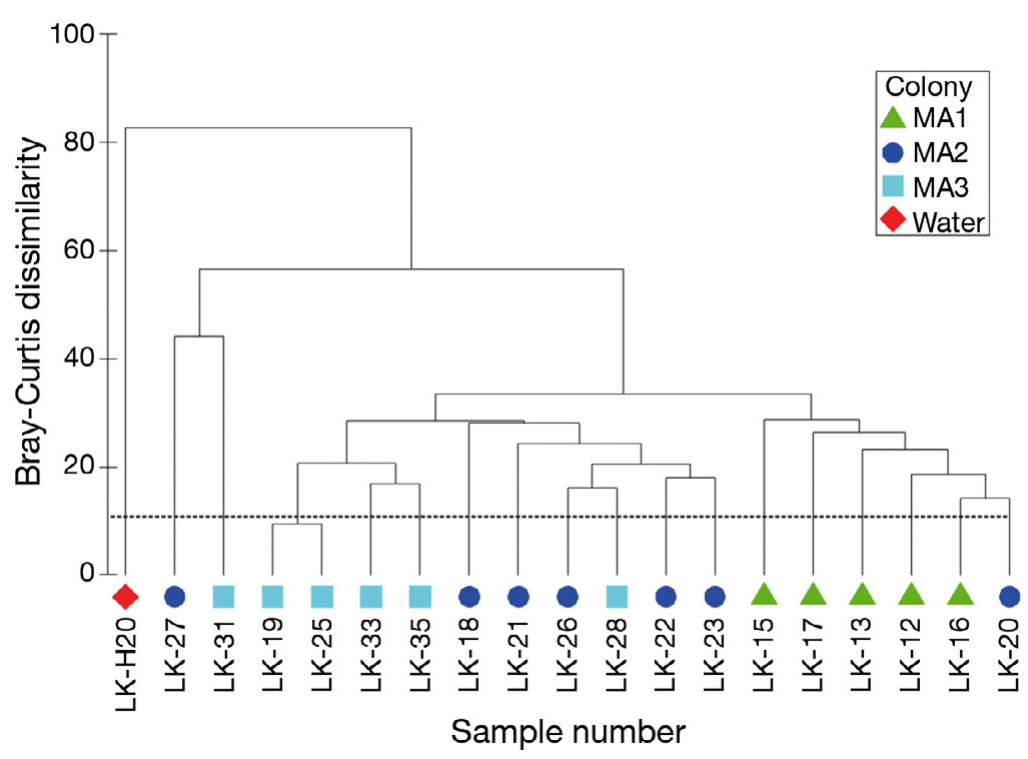

Fig. 3. Total bacteria community ARISA profiles on 3 Montastraea annularis colonies (see Fig. 1). The dotted horizontal line represents the average Bray-Curtis dissimilarity among triplicates to demonstrate methodological reproducibility

\section{TCBS counts of culturable Vibrio spp.}

In conjunction with surveying the total bacterial community, the culturable Vibrio fraction was examined in detail. Group-specific culturing for Vibrio spp., a Gram-negative bacterial group, was selected due to ease of cultivability, and the documented association of culturable Vibrio spp. with both healthy and bleached/ diseased corals (Ritchie et al. 1994, Ben-Haim et al.
1999, 2003b, Cervino et al. 2004, Breitbart et al. 2005, Ritchie 2006, Ainsworth et al. 2007, Hall-Spencer et al. 2007, Bourne et al. 2008). Plate counts and ARISA profiling were used to determine if the culturable Vibrio community displayed spatial heterogeneity across a coral colony.

Spatial variability in the abundance of culturable Vibrio spp. was observed across all 3 Montastraea annularis colonies (range: 27 to $533 \mathrm{CFU} \mathrm{ml}^{-1}$; Fig. 1). Mucus samples from different locations on the same coral colony produced highly variable numbers of culturable Vibrio spp. (up to 10-fold difference), with no discernable patterns based on the location of the sample on the coral colony (Fig. 1).

\section{Vibrio community profiles}

To determine if the composition of the Vibrio community demonstrated spatial heterogeneity across coral colonies, ARISA profiles were produced for the Vibrio spp. cultured from each mucus sample and the water column. The culturable Vibrio fraction contained an average of 37 OTUs. Only a single OTU (VP841) was present in every sample, where it only contributed an average of $1.6 \%$ of the Vibrio profile fluorescence. Four other OTUs (VP579, VP590, VP598, VP787) were conserved across most Montas-

Table 1. Phylogenetic assignments of common ARISA clones detected in Montastraea annularis total community profiles. Letters correspond to ARISA OTUs in Fig. 2. Bacterial group classification based on analysis of sequence in Ribosomal Database Project CLASSIFIER. OTU: operational taxonomic unit. See 'Materials and methods: Identification of ARISA OTUs' for details. nr database: non-redundant database number

\begin{tabular}{|c|c|c|c|c|c|}
\hline $\begin{array}{l}\text { OTU length } \\
\text { (bp) }\end{array}$ & Letter & $\begin{array}{l}\text { Accession } \\
\text { no. }\end{array}$ & $\begin{array}{l}\text { Closest NBCI match } \\
\text { (nr database) }\end{array}$ & $\begin{array}{l}\text { Nucleotide } \\
\text { identity }(\%)\end{array}$ & $\begin{array}{l}\text { Bacterial } \\
\text { group }\end{array}$ \\
\hline 393 & a & HM209393 & $\begin{array}{l}\text { Uncultured marine bacterium clone } \\
\text { SPOTSAPR01_5m146 DQ009152.1 }\end{array}$ & 92 & Gammaproteobacteria \\
\hline 405 & $\mathrm{~b}$ & HM209394 & $\begin{array}{l}\text { Uncultured marine bacterium clone } \\
\text { SPOTSAUG01_5m6 DQ009149.1 }\end{array}$ & 94 & Gammaproteobacteria \\
\hline 419 & C & HM209395 & $\begin{array}{l}\text { Uncultured marine bacterium clone } \\
\text { SPOTSOCT00_5m60 DQ009123.1 }\end{array}$ & 99 & Actinobacteria \\
\hline 681 & d & HM209396 & $\begin{array}{l}\text { Uncultured bacterium GRIST23 genomic } \\
\text { sequence EU795161.1 }\end{array}$ & 92 & Actinobacteria \\
\hline 697 & e & HM209397 & $\begin{array}{l}\text { Uncultured marine bacterium clone } \\
\text { SPOTSAPR01_5m18 DQ009159.1 }\end{array}$ & 85 & Gammaproteobacteria \\
\hline 740 & f & HM209398 & $\begin{array}{l}\text { Uncultured marine bacterium clone } \\
\text { SPOTSAUG01_5m55 DQ009099.1 }\end{array}$ & 83 & Bacteroidetes \\
\hline 767 & g & HM209399 & $\begin{array}{l}\text { Uncultured marine bacterium clone } \\
\text { SPOTSAPR01_5m146 DQ009084.1 }\end{array}$ & 73 & Bacteroidetes \\
\hline
\end{tabular}


traea annularis mucus samples, with these 4 OTUs totaling between 27 to $57 \%$ of the Vibrio community profile fluorescence for each sample. Three Vibrio OTUs (VP598, VP654, VP841) were also detected in the total community data. ANOSIM and PERMANOVA results for culturable Vibrio community profiles revealed no significant difference in Vibrio community profiles between colonies overall (1-way ANOSIM, $\mathrm{R}=0.14, \mathrm{p}=0.09$; PERMANOVA, $F=1.15$, $\mathrm{p}=0.25)$. Unlike the total community profiles, cluster analysis of Vibrio community data showed that the water column profile was similar to the mucus samples and did not result in grouping of mucus samples from the same coral colony (Fig. 4, VLK represents Vibrio Looe Key simple number). The average BrayCurtis dissimilarity value was $61 \%$, demonstrating that the structure of the Vibrio community was not determined by the colony from which the samples originated. Vibrio community samples collected from different locations on the same coral colony were as dissimilar to each other as samples from different coral colonies.

To help interpret the results from the Vibrio community profiles, ARISA profiles were produced for 10 individual Vibrio isolates cultured from a single location on each of the 3 Montastraea annularis colonies. An average of 16 peaks (size range 502-998 bp) were produced for each isolate, demonstrating that multiple OTUs observed in the community profiles could be attributed to a single isolate.

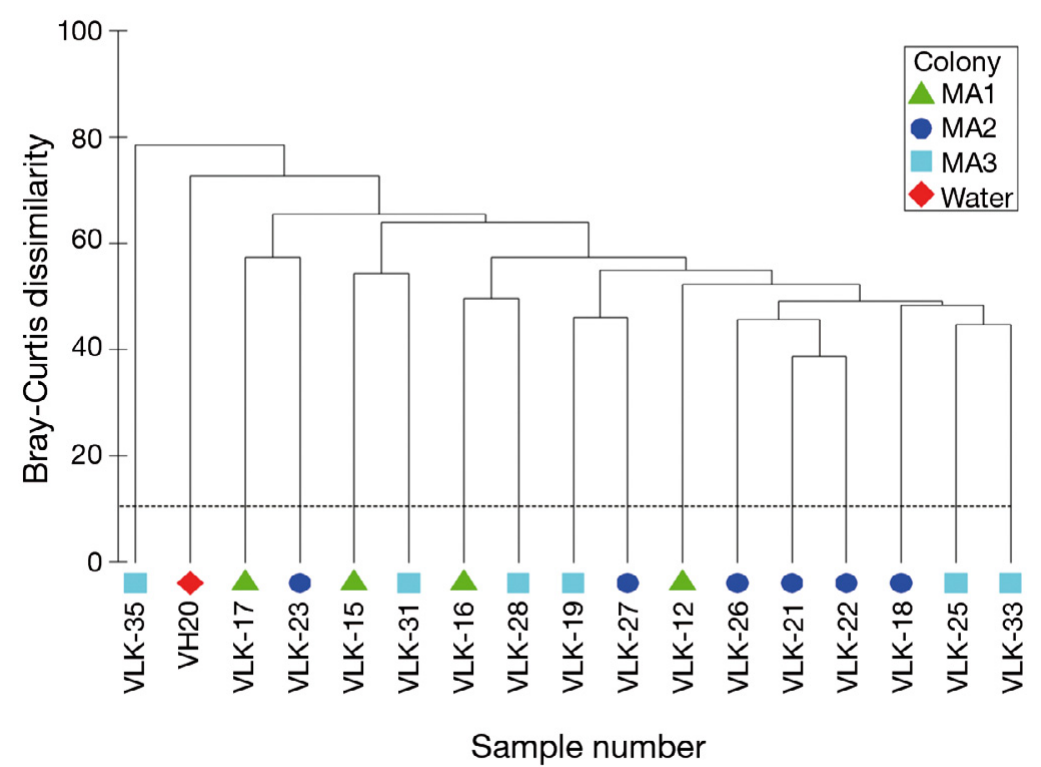

Fig. 4. Vibrio community ARISA profiles on 3 Montastraea annularis colonies (see Fig. 1). The dotted horizontal line represents the average Bray-Curtis dissimilarity among triplicates to demonstrate methodological repro-ducibility. VLK: Vibrio Looe Key (LK) sample number, location corresponds to LK sample number

\section{DISCUSSION}

Using a combination of culture-independent and culture-based analyses, this study documented withinand between-colony variability in the composition of the bacterial community in the mucus of healthy Montastraea annularis colonies in the Florida Keys. Total bacterial community composition between mucus samples and the water column were significantly different (Figs. 2 \& 3), which is consistent with previous reports that a coral's mucus layer contains bacterial communities that are distinct from the surrounding seawater (Rohwer et al. 2001). Some OTUs were shared between the coral and seawater samples, which was likely due to small amounts of seawater taken up when coral mucus samples were collected in situ by syringe. Total community ARISA data indicated significant variation between colonies within the same reef site. Most profiles grouped together with other samples from the same colony, however several exceptions were noted. Fig. 2 displays the abundance of a unique OTU (P451) in LK-27 and absence of many shared OTUs in LK-27 and LK-31, which could explain why these 2 samples are exceptions to the general observed grouping of samples from the same colony (Fig. 3). Several bacterial OTUs were detected in most or all of the coral samples, hence the low level of dissimilarity $(31 \%)$ in most profiles. However, total community profiles also revealed OTUs unique to individual locations within a coral colony. The disparate patterns observed for the Vibrio spp. as compared to the total community demonstrates that bacterial groups can exhibit different spatial structure across a coral colony.

The degree of spatial heterogeneity observed for coral-associated microbes in this study is similar to patterns observed for a variety of other host-associated microbial communities. Sponges are another example of benthic, sessile metazoa that contain a diverse bacterial assemblage throughout their ultrastructure (Thiel et al. 2007). A denaturing gradient gel electrophoresis (DGGE) survey of bacterial communities in multiple samples from 2 marine sponges Cymbastela concentric and Callyspongia sp. contained levels of within-individual heterogeneity $(\leq 30 \%$ dissimilarity) (Taylor et al. 2004) comparable to total community profile results in this study. In terrestrial systems, bacteria on individual plant leaves also display high levels of spatial heterogeneity (Beattie \& Lindow 1999, Andrews \& Harris 2000). Furthermore, $16 \mathrm{~S}$ rDNA pyro- 
sequencing studies have recently uncovered remarkable spatial heterogeneity of bacteria associated with human hosts. Less than $1 \%$ of all OTUs were shared among 27 different locations on the human body (Costello et al. 2009).

The consistent detection of a few bacterial OTUs from Montastraea annularis in this study parallels previous studies demonstrating that certain bacteria are specifically associated with some coral species (Rohwer et al. 2002, Casas et al. 2004). Prior studies have shown that some bacterial OTUs can be found throughout a colony, but other OTUs are only detected at certain locations on a colony. For example, Rohwer et al. (2002) detected a specific gammaproteobacteria (PF1) at multiple locations across Porites furcata colonies, yet also consistently identified a unique bacterial OTU found on the tips of $P$. furcata branches that was absent from samples taken at the colony bases. Pocillopora damicornis also exhibited both intercolony conservation and intracolony patchiness (Bourne \& Munn 2005), and similar patterns have recently been detected in the cold water coral, Madrepora oculata (Hansson et al. 2009). Guppy \& Bythell (2006) observed within-colony spatial variation in the boulder coral, Montastraea faveolata, but overall the samples from an individual reef site were not significantly different, leading to the conclusion that a single sample could represent the bacterial community for an entire coral colony. While that study addressed ecosystem-wide scales, this study focused explicitly on centimeter-scale variability within individual colonies. Individual sample profiles within a colony exhibited small-scale variation, where OTUs were reduced in abundance or completely absent (see Figs. 2 \& 3; LK-16 vs. LK-17) from locations centimeters apart.

The genus Vibrio is a ubiquitous group of marine bacteria containing members found in healthy coral specimens (Alves et al. 2010) and also implicated in a number of coral diseases (Ben-Haim et al. 2003b, Cervino et al. 2008, Sussman et al. 2008). Vibrio spp. abundances have been observed to increase in reef communities across gradients of increasing dissolved nutrients, pathogens, and human populations (Dinsdale et al. 2008). Ambient bacterial communities in corals are known to shift in structure and become dominated by Vibrio spp. during incidences of coral bleaching or disease (Ritchie \& Smith 1995, Bourne \& Munn 2005, Koren \& Rosenberg 2006, Ritchie 2006, Bourne et al. 2008). However, previous studies have not elucidated whether this component of the community is evenly distributed across individual healthy colonies. In this study, a great deal of spatial heterogeneity in the abundance of culturable Vibrio spp. was observed across individual healthy coral colonies (up to 10 -fold variation). It is possible that differing amounts of coral mucus were obtained in the $12 \mathrm{ml}$ samples collected by syringe, which could have contributed to the Vibrio community variability. In addition, it is also possible that the areas of the coral with higher Vibrio spp. abundances may have been experiencing stress or disease conditions despite being visually indistinguishable from the rest of the coral colony. Although prior studies have observed higher abundances of Vibrio spp. associated with diseased corals, there is not a standard sample type or volume used for comparing Vibrio counts in healthy versus diseased corals. The high degree of spatial heterogeneity in the abundance of culturable Vibrio spp. observed on apparently healthy corals in this study demonstrates that Vibrio abundance should not be used, independent of other tests, as a diagnostic of coral health.

In contrast to the total community profiles where the coral-associated bacteria were significantly different types than those found in the overlying water column, ARISA profiles of culturable Vibrio communities from the water sample clustered with the coral mucus samples (Fig. 4). Despite much focus on pathogenicity, this and previous studies have consistently detected Vibrio spp. in healthy coral samples. However, the coralassociated Vibrio spp. did not form a distinct cluster from those in the water column, which supports the idea that vibrios are 'visitors' as opposed to 'residents' of the coral microbiome (Ritchie 2006). Composition of the culturable Vibrio community was highly variable across individual colonies and samples from the same coral colony did not cluster together. Intracolony heterogeneity in the composition of the Montastraea annularis culturable Vibrio community rivaled intercolony variation (Fig. 4). Although the Vibrio communities across $M$. annularis coral colonies were very different (61\% dissimilar), there may still be some conservation of certain Vibrio spp. in M. annularis, given that 3 Vibrio OTUs were shared among all 3 coral colonies.

Individual Vibrio isolates were shown to produce numerous ARISA peaks, demonstrating that each peak on the ARISA profile does not necessarily represent a different OTU. It is not unusual that individual Vibrio isolates produced numerous ARISA peaks, as Vibrio spp. are known to contain multiple rRNA copies within their genomes (Crosby \& Criddle 2003, Acinas et al. 2004, Stewart \& Cavanaugh 2007) and thus do not follow the 'one bacteria, one peak' assumption. The multiple rRNA copy number complicates comparisons of Vibrio community profiles between samples, since the differences between profiles may be attributable to one or more isolates. We must also consider that culturing fails to capture most bacteria (Staley \& Konopka 1985, Amann et al. 1995). 
Many bacteria, including Vibrio spp. have been shown to enter viable but non-culturable phases (Xu et al. 1982, Colwell et al. 1985, Oliver et al. 1995), during periods of starvation and environmental stress, and will only re-grow under certain conditions (Gauthier 2000, Vattakaven et al. 2006).

Many different factors might have contributed to the observed heterogeneity in bacterial community composition. Different locations on a coral colony may be impacted by varying degrees of light exposure, nutrient availability, currents, sedimentation, mucus age, and competition with other microbes (Brown \& Bythell 2005, Shnit-Orland \& Kushmaro 2009, Teplitski \& Ritchie 2009, Rypien et al. 2010). Ritchie (2006) observed that mucus plays a strong role in structuring the bacterial community, with antibiotic activity inhibiting the growth of potential pathogens. Furthermore, that study demonstrated that environmental stress altered the regulatory capacity of native mucus bacteria (i.e. loss of antibiotic production), which allowed for the settlement of opportunists (Ritchie 2006). The variation in mucus composition among coral species (Ducklow \& Mitchell 1979b) and during times of stress (Ritchie \& Smith 1995) has previously been used to explain differences in coral-associated bacterial communities. However, these explanations can be extended to intracolony scales, where bacteria are influenced by physical, chemical, and biological factors when competing to fill microniches. The small-scale variation (centimeters apart) described here may explain why some signs of coral disease initiate at what appear to be random locations on a coral's surface.

The significant spatial heterogeneity in both the composition of the total bacterial community, as well as in the abundance and diversity of culturable Vibrio spp., has important implications for experimental design of coral microbiology studies. Often, research on coral-associated bacteria is based on a single point sample collected from the surface of a coral colony. The high degree of spatial variability described in this study demonstrates that a single point sample may not be representative of the total coral-associated bacterial community. In addition, caution is needed when interpreting differences in point samples collected from different coral colonies, since these differences may be attributable to spatial heterogeneity on each colony instead of actual intercolony variation. As suggested by Hansson et al. (2009), an appropriate sample needs to integrate over the entire coral colony, or multiple spatially-distinct samples from each colony need to be obtained. However, caution also must be used when interpreting results from whole-colony surface samples, since these composites average over many highly variable microscales.
In addition to the implications for coral microbiology research, this study also has practical applications for coral restoration projects. Coral aquaculture and transplantation are currently being employed to address worldwide decline of coral reefs and promote reef ecosystem recovery (Abelson 2006). Although the introduction of pathogens from aquaculture to natural reef systems is a significant concern with coral restoration projects, there are currently no microbiological assessments included in health certification procedures prior to returning coral fragments to the wild. The complex nature of the coral-associated microbial community has made it difficult to establish a 'healthy baseline' for these microbes. Examining spatial heterogeneity of microbial communities across individual coral colonies is crucial for coral restoration projects because each of the fragments used for restoration originates from a different location on the original parent coral colony. Overall, significant heterogeneity was observed in the bacterial community within individual coral colonies, demonstrating that fragments originating from the same colony do not contain identical bacterial communities. Until knowledge improves regarding the variability of microbial community composition on healthy corals and the specific pathogens responsible for coral diseases, it will be difficult to incorporate microbial parameters into health assessments for restoration projects.

Acknowledgements. This research was funded by grants to I.B. from Florida's Wildlife Initiative-Florida State Wildlife Grants Program and to M.B. from the Project AWARE Foundation and the Mote Marine Laboratory Protect Our Reefs Grants Program, which is funded by proceeds from the sale of the Protect Our Reefs specialty license plate (www.mote. org/4reef). Shiptime on the RV 'Bellows' for sampling was provided by the Florida Institute of Oceanography. Mucus samples collected in the Florida Keys National Marine Sanctuary were obtained under permits issued to K.B.R. (FKNMS2008-065). We thank C. Coy and R. Cjzada (Florida Aquarium), B. Dent (USF), E. Bartels (Mote Marine Laboratory), and S. Graves (University of Florida Tropical Aquaculture Laboratory), who were instrumental in field and dive support. Thanks to R. Schmieder for dialogue on ARISA profiling, and D. Mann and D. Jones for help with statistical analyses.

\section{LITERATURE CITED}

Abelson A (2006) Artificial reefs vs. coral transplantation as restoration tools for mitigating coral reef deterioration: benefits, concerns, and proposed guidelines. Bull Mar Sci 78:151-159

Acinas SG, Marcelino LA, Klepac-Ceraj V, Polz MF (2004) Divergence and redundancy of $16 \mathrm{~S}$ rRNA sequences in genomes with multiple rrn operons. J Bacteriol 186: 2629-2635

> Ainsworth TD, Fine M, Blackall LL, Hoegh-Guldberg O (2006) Fluorescence in situ hybridization and spectral imaging of coral-associated bacterial communities. Appl Environ Microbiol 72:3016-3020 
Ainsworth TD, Fine M, Roff G, Hoegh-Guldberg O (2007) Bacteria are not the primary cause of bleaching in the Mediterranean coral Oculina patagonica. ISME J 2: $67-73$

Altschul SF, Gish W, Miller W, Myers EW, Lipman DJ (1990) Basic local alignment search tool. J Mol Biol 215:403-410

- Alves Jr N, Neto OSM, Silva BSO, De Moura RL and others (2010) Diversity and pathogenic potential of vibrios isolated from Abrolhos Bank corals. Environ Microbiol Rep 2: 90-95

Amann RI, Ludwig W, Schleifer KH (1995) Phylogenetic identification and in-situ detection of individual microbial cells without cultivation. Microbiol Rev 59:143-169

- Anderson MJ (2001) A new method for non-parametric multivariate analysis of variance. Austral Ecol 26:32-46

> Anderson MJ (2006) Distance-based tests for homogeneity of multivariate dispersions. Biometrics 62:245-253

Andrews JH, Harris RF (2000) The ecology and biogeography of microorganisms on plant surfaces. Annu Rev Phytopathol 38:145-180

Beattie GA, Lindow SE (1999) Bacterial colonization of leaves: a spectrum of strategies. Phytopathology 89:353-359

> Beman JM, Roberts KJ, Wegley L, Rohwer F, Francis CA (2007) Distribution and diversity of archaeal ammonia monooxygenase genes associated with corals. Appl Environ Microbiol 73:5642-5647

Ben-Haim Y, Banim E, Kushmaro A, Loya Y, Rosenberg E (1999) Inhibition of photosynthesis and bleaching of zooxanthellae by the coral pathogen Vibrio shiloi. Environ Microbiol 1:223-229

Ben-Haim Y, Thompson FL, Thompson CC, Cnockaert MC, Hoste B, Swings J, Rosenberg E (2003a) Vibrio coralliilyticus sp. nov., a temperature-dependent pathogen of the coral Pocillopora damicornis. Int J Syst Evol Microbiol 53:309-315

Ben-Haim Y, Zicherman-Keren M, Rosenberg E (2003b) Temperature-regulated bleaching and lysis of the coral Pocillopora damicornis by the novel pathogen Vibrio coralliilyticus. Appl Environ Microbiol 69:4236-4242

Borneman J, Triplett EW (1997) Molecular microbial diversity in soils from eastern Amazonia: evidence for unusual microorganisms and microbial population shifts associated with deforestation. Appl Environ Microbiol 63: 2647-2653

Bourne DG, Munn CB (2005) Diversity of bacteria associated with the coral Pocillopora damicornis from the Great Barrier Reef. Environ Microbiol 7:1162-1174

Bourne D, Iida Y, Uthicke S, Smith-Keune C (2008) Changes in coral-associated microbial communities during a bleaching event. ISME J 2:350-363

Bray JR, Curtis JT (1957) An ordination of the upland forest communities of southern Wisconsin. Ecol Monogr 27: 325-349

Breitbart M, Bhagooli R, Griffin S, Johnston I, Rohwer F (2005) Microbial communities associated with skeletal tumors on Porites compressa. FEMS Microbiol Lett 243: 431-436

> Brown BE, Bythell JC (2005) Perspectives on mucus secretion in reef corals. Mar Ecol Prog Ser 296:291-309

> Brown MV, Schwalbach MS, Hewson I, Fuhrman JA (2005) Coupling 16S-ITS rDNA clone libraries and automated ribosomal intergenic spacer analysis to show marine microbial diversity: development and application to a time series. Environ Microbiol 7:1466-1479

> Casas V, Kline DI, Wegley L, Yu YN, Breitbart M, Rohwer F (2004) Widespread association of a Rickettsiales-like bacterium with reef-building corals. Environ Microbiol 6: $1137-1148$
Cervino JM, Hayes RL, Polson SW, Polson SC, Goreau TJ, Martinez RJ, Smith GW (2004) Relationship of Vibrio species infection and elevated temperatures to yellow blotch/band disease in Caribbean corals. Appl Environ Microbiol 70:6855-6864

Cervino JM, Thompson FL, Gomez-Gil B, Lorence EA and others (2008) The Vibrio core group induces yellow band disease in Caribbean and Indo-Pacific reef-building corals. J Appl Microbiol 105:1658-1671

Clarke KR (1993) Nonparametric multivariate analyses of changes in community structure. Aust J Ecol 18:117-143

Colwell RR, Brayton PR, Grimes DJ, Roszak DB, Huq SA, Palmer LM (1985) Viable but non-culturable Vibrio cholerae and related pathogens in the environment: implications for release of genetically engineered microorganisms. Biotechnology (N Y) 3:817-820

Costello EK, Lauber CL, Hamady M, Fierer N, Gordon JI, Knight R (2009) Bacterial community variation in human body habitats across space and time. Science 326: 1694-1697

Crosby LD, Criddle CS (2003) Understanding bias in microbial community analysis techniques due to rrn operon copy number heterogeneity. Biotechniques 34:790-794

Danovaro R, Luna GM, Dell'Anno A, Pietrangeli B (2006) Comparison of two fingerprinting techniques, terminal restriction fragment length polymorphism and automated ribosomal intergenic spacer analysis, for determination of bacterial diversity in aquatic environments. Appl Environ Microbiol 72:5982-5989

Dinsdale EA, Pantos O, Smriga S, Edwards RA and others (2008) Microbial ecology of four coral atolls in the Northern Line Islands. PLoS ONE 3:e1584

Ducklow HW, Mitchell R (1979a) Bacterial populations and adaptations in the mucus layers on living corals. Limnol Oceanogr 24:715-725

> Ducklow HW, Mitchell R (1979b) Composition of mucus released by coral-reef coelenterates. Limnol Oceanogr 24: 706-714

> Fisher MM, Triplett EW (1999) Automated approach for ribosomal intergenic spacer analysis of microbial diversity and its application to freshwater bacterial communities. Appl Environ Microbiol 65:4630-4636

> Frias-Lopez J, Zerkle AL, Bonheyo GT, Fouke BW (2002) Partitioning of bacterial communities between seawater and healthy, black band diseased, and dead coral surfaces. Appl Environ Microbiol 68:2214-2228

Gauthier J (2000) Environmental parameters associated with the viable but nonculturable state. In: Colwell RR, Grimes DJ (eds) Nonculturable microorganisms in the environment. ASM Press, Washington, DC, p 87-112

Gil-Agudelo DL, Myers C, Smith GW, Kim K (2006) Changes in the microbial communities associated with Gorgonia ventalina during aspergillosis infection. Dis Aquat Org 69:89-94

Gil-Agudelo DL, Fonseca DP, Weil E, Garzon-Ferreira J, Smith GW (2007) Bacterial communities associated with the mucopolysaccharide layers of three coral species affected and unaffected with dark spots disease. Can J Microbiol 53:465-471

Guppy R, Blythell, JC (2006) Environmental effects on bacterial diversity in the surface mucus layer of the reef coral Montastraea faveolata. Mar Ecol Prog Ser 328:133-142

> Hall-Spencer JM, Pike J, Munn CB (2007) Diseases affect cold-water corals too: Eunicella verrucosa (Cnidaria: Gorgonacea) necrosis in SW England. Dis Aquat Org 76:87-97

> Hansson L, Agis M, Maier C, Weinbauer MG (2009) Community composition of bacteria associated with cold-water 
coral Madrepora oculata: within and between colony variability. Mar Ecol Prog Ser 397:89-102

- Hewson I, Fuhrman JA (2004) Richness and diversity of bacterioplankton species along an estuarine gradient in Moreton Bay, Australia. Appl Environ Microbiol 70: 3425-3433

> Hewson I, Fuhrman JA (2006) Improved strategy for comparing microbial assemblage fingerprints. Microb Ecol 51: $147-153$

Johnston IS, Rohwer F (2007) Microbial landscapes on the outer tissue surfaces of the reef-building coral Porites compressa. Coral Reefs 26:375-383

Kline DI, Kuntz NM, Breitbart M, Knowlton N, Rohwer F (2006) Role of elevated organic carbon levels and microbial activity in coral mortality. Mar Ecol Prog Ser 314: $119-125$

Kooperman N, Ben-Dov E, Kramarsky-Winter E, Barak Z, Kushmaro A (2007) Coral mucus-associated bacterial communities from natural and aquarium environments. FEMS Microbiol Lett 276:106-113

> Koren O, Rosenberg E (2006) Bacteria associated with mucus and tissues of the coral Oculina patagonica in summer and winter. Appl Environ Microbiol 72:5254-5259

Kushmaro A, Rosenberg E, Fine M, Loya Y (1997) Bleaching of the coral Oculina patagonica by Vibrio AK-1. Mar Ecol Prog Ser 147:159-165

Kushmaro A, Banin E, Loya Y, Stackebrandt E, Rosenberg E (2001) Vibrio shiloi sp. nov., the causative agent of bleaching of the coral Oculina patagonica. Int J Syst Evol Microbiol 51:1383-1388

Lesser MP, Mazel CH, Gorbunov MY, Falkowski PG (2004) Discovery of symbiotic nitrogen-fixing cyanobacteria in corals. Science 305:997-1000

Lotz MJ, Tamplin ML, Rodrick GE (1983) Thiosulfate-citratebile salts-sucrose agar and its selectivity for clinical and marine vibrio organisms. Ann Clin Lab Sci 13:45-48

Luna GM, Dell'Anno A, Danovaro R (2006) DNA extraction procedure: a critical issue for bacterial diversity assessment in marine sediments. Environ Microbiol 8: 308-320

> Nissimov J, Rosenberg E, Munn CB (2009) Antimicrobial properties of resident coral mucus bacteria of Oculina patagonica. FEMS Microbiol Lett 292:210-215

> Oliver JD, Hite F, McDougald D, Andon NL, Simpson LM (1995) Entry into, and resuscitation from, the viable but nonculturable state by Vibrio vulnificus in an estuarine environment. Appl Environ Microbiol 61:2624-2630

> Pantos O, Bythell JC (2006) Bacterial community structure associated with white band disease in the elkhorn coral Acropora palmata determined using culture-independent 16S rRNA techniques. Dis Aquat Org 69:79-88

Pantos O, Cooney RP, Le Tissier MDA, Barer MR, O'Donnell AG, Bythell JC (2003) The bacterial ecology of a plaguelike disease affecting the Caribbean coral Montastrea annularis. Environ Microbiol 5:370-382

Ramette A (2009) Quantitative community fingerprinting methods for estimating the abundance of operational taxonomic units in natural microbial communities. Appl Environ Microbiol 75:2495-2505

Reshef L, Koren O, Loya Y, Zilber-Rosenberg I, Rosenberg E (2006) The coral probiotic hypothesis. Environ Microbiol 8:2068-2073

Ritchie KB (2006) Regulation of microbial populations by coral surface mucus and mucus-associated bacteria. Mar Ecol Prog Ser 322:1-14

Ritchie KB, Smith GW (1995) Preferential carbon utilization by surface bacterial communities from water mass, nor- mal, and white-band diseased Acropora cervicornis. Mol Mar Biol Biotechnol 4:345-352

Ritchie KB, Smith GW (1997) Physiological comparison of bacterial communities from various species of scleractinian corals. Proc 8th Intl Coral Reef Symp, Panama p 521-526

Ritchie KB, Smith GW (2004) Microbial communities of coral surface mucopolysaccharide layers. In: Rosenberg E, Loya $\mathrm{Y}$ (eds) Coral health and disease. Springer-Verlag, New York, NY, p 259-263

Ritchie KB, Dennis JH, McGrath T, Smith GW (1994) Bacteria associated with bleached and nonbleached areas of Monastrea annularis. Proc 5th Symp Nat Hist, San Salvador, Bahamas p 75-80

Rohwer F, Breitbart M, Jara J, Azam F, Knowlton N (2001) Diversity of bacteria associated with the Caribbean coral Montastraea franksi. Coral Reefs 20:85-91

Rohwer F, Seguritan V, Azam F, Knowlton N (2002) Diversity and distribution of coral-associated bacteria. Mar Ecol Prog Ser 243:1-10

Rohwer F, Youle M, Vosten D (2010) Coral reefs in the microbial seas. Plaid Press, Basalt, CO

> Rosenberg E, Koren O, Reshef L, Efrony R, Zilber-Rosenberg I (2007) The role of microorganisms in coral health, disease and evolution. Nat Rev Microbiol 5:355-362

Rypien KL, Ward JR, Azam F (2010) Antagonistic interactions among coral-associated bacteria. Environ Microbiol 12: $28-39$

Sekar R, Mills DK, Remily ER, Voss JD, Richardson LL (2006) Microbial communities in the surface mucopolysaccharide layer and the black band microbial mat of black banddiseased Siderastrea siderea. Appl Environ Microbiol 72: 5963-5973

Shashar N, Cohen Y, Loya Y, Sar N (1994) Nitrogen-fixation (acetylene-reduction) in stony corals: evidence for coral-bacteria interactions. Mar Ecol Prog Ser 111: $259-264$

Shnit-Orland M, Kushmaro A (2009) Coral mucus-associated bacteria: a possible first line of defense. FEMS Microbiol Ecol 67:371-380

Smith JE, Shaw M, Edwards RA, Obura D and others (2006) Indirect effects of algae on coral: algae-mediated, microbe-induced coral mortality. Ecol Lett 9:835-845

Staley JT, Konopka A (1985) Measurement of in situ activities of nonphotosynthetic microorganisms in aquatic and terrestrial habitats. Annu Rev Microbiol 39:321-346

> Stewart FJ, Cavanaugh CM (2007) Intragenomic variation and evolution of the internal transcribed spacer of the rRNA operon in bacteria. J Mol Evol 65:44-67

Sussman M, Willis BL, Victor S, Bourne DG (2008) Coral pathogens identified for White Syndrome (WS) epizootics in the Indo-Pacific. PLoS ONE 3:e2393

Taylor MW, Schupp PJ, Dahllof I, Kjelleberg S, Steinberg PD (2004) Host specificity in marine sponge-associated bacteria, and potential implications for marine microbial diversity. Environ Microbiol 6:121-130

Teplitski M, Ritchie K (2009) How feasible is the biological control of coral diseases? Trends Ecol Evol 24:378-385

> Thiel V, Neulinger SC, Staufenberger T, Schmaljohann R, Imhoff JF (2007) Spatial distribution of sponge-associated bacteria in the Mediterranean sponge Tethya aurantium. FEMS Microbiol Ecol 59:47-63

Vattakaven T, Bond P, Bradley G, Munn CB (2006) Differential effects of temperature and starvation on induction of the viable-but-nonculturable state in the coral pathogens Vibrio shiloi and Vibrio tasmaniensis. Appl Environ Microbiol 72:6508-6513 
Wang Q, Garrity GM, Tiedje JM, Cole JR (2007) Naive Bayesian classifier for rapid assignment of rRNA sequences into the new bacterial taxonomy. Appl Environ Microbiol 73:5261-5267

Wegley L, Yu YN, Breitbart M, Casas V, Kline DI, Rohwer F (2004) Coral-associated Archaea. Mar Ecol Prog Ser 273: 89-96

> Wegley L, Edwards R, Rodriguez-Brito B, Liu H, Rohwer F (2007) Metagenomic analysis of the microbial community associated with the coral Porites astreoides. Environ

Editorial responsibility: Charles Birkeland,

Honolulu, Hawaii, USA
Microbiol 9:2707-2719

Wild C, Huettel M, Klueter A, Kremb SG, Rasheed MYM, Jorgensen BB (2004) Coral mucus functions as an energy carrier and particle trap in the reef ecosystem. Nature 428:66-70

Xu HS, Roberts N, Singleton FL, Attwell RW, Grimes DJ, Colwell RR (1982) Survival and viability of nonculturable Escherichia coli and Vibrio cholerae in the estuarine and marine environment. Microb Ecol 8:313-323

Submitted: May 15, 2010; Accepted: January 6, 2011

Proofs received from author(s): March 11, 2011 